\title{
MICROSTRUCTURAL CHANGES IN CEMENT MORTAR DUE TO AN ALKALI-CARBONATE REACTION
}

\author{
SPREMEMBE MIKROSTRUKTURE CEMENTNE MALTE ZARADI \\ ALKALNO-KARBONATNE REAKCIJE
}

\author{
Petra Štukovnik $^{1}$, Violeta Bokan Bosiljkov ${ }^{1}$, Marjan Marinšek ${ }^{2}$ \\ ${ }^{1}$ University of Ljubljana, Faculty of Civil and Geodetic Engineering, Jamova cesta 2, 1000 Ljubljana \\ ${ }^{2}$ University of Ljubljana, Faculty of Chemistry and Chemical Technology, Večna pot 113, 1000 Ljubljana
}

Prejem rokopisa - received: 2018-12-11; sprejem za objavo - accepted for publication: 2018-12-20

doi:10.17222/mit.2018.266

\begin{abstract}
This paper investigates the process of an alkali-carbonate reaction (ACR) in cement mortar in the time frame of 1 year. The mortar bars $(40 \mathrm{~mm} \times 40 \mathrm{~mm} \times 160 \mathrm{~mm}$ ) were prepared using dolomite of the Triassic age from the south-eastern part of Slovenia as a source of crushed stone aggregate. As a binder, Portland cement CEM I 52.5 R was used. The hardened mortar bars were exposed to accelerated ageing conditions simulated by $1-\mathrm{M} \mathrm{NaOH}$ at $60{ }^{\circ} \mathrm{C}$ or deionized water at $60{ }^{\circ} \mathrm{C}, 28 \mathrm{~d}$ after casting. The aged mortar samples were investigated using optical microscopy, SEM and XRD. The obtained results revealed that chemical reactions characteristic for the ACR progressed in all the analysed samples. Additionally, new $\mathrm{Mg}-\mathrm{Al}, \mathrm{Mg}-\mathrm{Si}$ and $\mathrm{Mg}$-Al-Si gel-like phases were detected at the aggregate-cement paste interface. The influence of the ACR on the mechanical properties of the cement mortar was studied through the flexural and compressive strength and the elasticity modulus of mortar bars.

Keywords: alkali carbonate reaction (ACR), dedolomitisation, formation of new $\mathrm{Mg}-\mathrm{Al}, \mathrm{Mg}-\mathrm{Si}$ and $\mathrm{Mg}-\mathrm{Al}-\mathrm{Si}$ phases

Članek prikazuje proces alkalno karbonatne reakcije v cementni malti v časovnem obdobju enega leta. Prizmatični vzorci cementne malte $(40 \mathrm{~mm} \times 40 \mathrm{~mm} \times 160 \mathrm{~mm})$ so bili pripravljeni z drobljenim dolomitnim agregatom triasne starosti, iz kamnoloma v jugo-vzhodnem delu Slovenije. Kot vezivo je bil uporabljen čisti portlandski cement CEM I 52.5 R. Po 28 dneh staranja smo maltne prizme izpostavili še pospešenim pogojem staranja, ki smo jih simulirali z $1 \mathrm{M}$ raztopino NaOH ali deionizirano vodo pri temperaturi $60^{\circ} \mathrm{C}$. Na postaranih vzorcih smo v obdobju enega leta uspešno zaznali alkalno karbonatno reakcijo in natančno spremljali pripadajoče procese s pomočjo optične in vrstične elektronske mikroskopije (SEM) ter rentgenske difrakcije (XRD). Ti procesi so dedolomitizacija ter oblikovanje novih $\mathrm{Mg}-\mathrm{Al}, \mathrm{Mg}-\mathrm{Si}$ in $\mathrm{Mg}-\mathrm{Al}-\mathrm{Si}$ faz, $\mathrm{ki}$ se praviloma pojavijo med dedolomitiziranimi zrni agregata in cementnim vezivom. Vpliv teh procesov na mehanske lastnosti cementne malte smo preučevali s pomočjo ugotavljanja upogibne in tlačne trdnosti ter modula elastičnosti prizmatičnih vzorcev.

Ključne besede: alkalno karbonatna reakcija (ACR), dedolomitizacija, oblikovanje Mg-Al, Mg-Si in Mg-Al-Si faz
\end{abstract}

\section{INTRODUCTION}

In Slovenia the majority of crushed aggregates used for concretes and mortars production originate from carbonate rocks, limestone, dolomitic limestone, calcite dolomite and dolomite, according to the classification of rocks given in M. R. Smith. ${ }^{1}$ Recently, it was discovered that late diagenetic dolomite of the Triassic age from the northern part of Slovenia, when used as crushed aggregate in cement mortars, can undergo chemical reactions when aged..$^{2-4}$ For this reason, chemical alterations that involve carbonate rocks with dolomite crystals and hydrated cement paste have recently been a subject of intensive investigation due to their importance for the development of microstructural, physical and mechanical properties in aged concretes. ${ }^{2,4-10}$ It has been shown that some phase transformations and subsequent concretedeterioration phenomena during aging can be explained by the so-called alkali-carbonate reaction (ACR). The basic concept of the ACR reaction is widely accepted

*Corresponding author e-mail:

marjan.marinsek@fkkt.uni-lj and is described in brief as follows. ${ }^{7}$ Dolomite crystals, present in the carbonate aggregates, interact with the hydroxide ions from the pore solution, causing its decomposition and the intergrowth of calcite and brucite. The carbonate ions, released during this so-called dedolomitisation reaction, migrate into the hydrated cement paste and assist in portlandite dissolution. Thus released $\mathrm{Ca}^{2+}$ ions react with carbonate ions to form a secondary calcium carbonate (carbonate halo) around the decaying dolomite aggregate grain. Such a reaction scheme will maintain the pore solution alkalinity due to the regeneration of the alkali hydroxide. In the literature, the dedolomitsation process has been reported mostly on carbonate aggregates including reactive silica. ${ }^{7,8,11,12}$

The aim of this work is to further reveal the mechanism of the ACR reaction. For this purpose, cement mortar with a silica-free dolomite aggregate from the south-eastern part of Slovenia was used and submitted to an accelerated ACR reaction at $60{ }^{\circ} \mathrm{C}$ in highly alkaline media or simply in aqueous media. The microstructure alterations of aged mortar were investigated by means of optical microscopy, SEM and qualitative SEM-EDS analysis. These microstructure observations together 
P. ŠTUKOVNIK et al.: MICROSTRUCTURAL CHANGES IN CEMENT MORTAR DUE TO ...

Tabela 1: Kemijska sestava cementa CEM I

\begin{tabular}{|c|c|c|c|c|c|c|c|c|c|}
\hline Oxide (\%) & $\mathrm{SiO}_{2}$ & $\mathrm{CaO}$ & $\mathrm{MgO}$ & $\mathrm{Al}_{2} \mathrm{O}_{3}$ & $\mathrm{Fe}_{2} \mathrm{O}_{3}$ & $\mathrm{SO}_{3}$ & $\mathrm{Na}_{2} \mathrm{O}$ & $\mathrm{K}_{2} \mathrm{O}$ & $\mathrm{Cl}$ \\
\hline CEM I & 19.5 & 62.3 & 1.6 & 4.6 & 3.0 & 3.4 & 0.3 & 0.8 & $/$ \\
\hline
\end{tabular}

with XRD analyses were further related to the measured flexural and compressive strengths, and the modulus of elasticity of the aged mortar bars.

\section{EXPERIMENTAL PART}

\subsection{Materials and methods}

\subsubsection{Materials}

The mortar mixture was prepared using typical dolomite aggregate from the south-eastern part of Slovenia and Portland cement CEM I 52.5 R (EN 197-1) from a Slovenian cement producer. The Blain specific surface area of the used cement was $4770 \mathrm{~cm}^{2} \mathrm{~g}^{-1}$, and its density was $3.11 \mathrm{~g} \mathrm{~cm}^{-3}$. The chemical composition of the cement is given in Table $\mathbf{1}$.

Triassic age rocks are the most prevalent of all rocks in Slovenia. Dolomite rock used as a source of the crushed aggregate in this investigation was middle-age Triassic dolomite $\left(\mathrm{T}_{2+3}\right)$. This type of dolomite is often of light to dark grey colour, with coarse grained crystals..$^{13,14}$ For the mortar preparation an aggregate fraction $0 / 4 \mathrm{~mm}$ was used. The water absorption of the aggregate was $0.2 \%$, and its density was $2810 \mathrm{~kg} / \mathrm{m}^{3}$. The result of the mineralogical quantitative X-ray analysis showed that dolomite represents $98.1 \%$ of the mineral content in the used aggregate, and calcite represents $\approx 1.9 \%$.

\subsubsection{Analytical methods}

Microstructure characterizations of the samples were performed by means of optical microscopy (a polarizing optical microscope with transmitted light, NIXON Eclipse E 200). The samples in the form of thin sections $(15-20 \mu \mathrm{m})$ were prepared from the mortar bars in accordance with the descriptions in. ${ }^{15,16}$ Electron microscopy was done using a FE-SEM Zeiss Ultra Plus microscope equipped with an EDS Oxford X-Max SDD $50 \mathrm{~mm}^{2} 106$ detector and INCA $4.145 \mathrm{X}$-ray microanalysis software.

As a supplementary analysis to identify the crystalline phases' development in aged mortar bars, X-ray powder diffraction (XRD) was carried out on powdered slice chips of mortar samples, whose counterparts were used for thin sectioning, with $\mathrm{Cu}-\mathrm{K}_{\alpha}$ radiation $(\lambda=0.154$ $\mathrm{nm}$ ) in the $2 \theta$ range between $20^{\circ}$ and $70^{\circ}$ using an XPert Pro X-ray diffractometer. A quantitative phase analysis of the samples was done using the Rietveld method.

The flexural (3 parallel samples) and compressive (6 parallel samples) strengths of the mortar bars were determined according to the EN 1015-11 standard, by using testing machines with capacities of $100 \mathrm{kN}$ and $500 \mathrm{kN}$, respectively.
The dynamic modulus of elasticity was measured on 3 parallel samples, by using GrindoSonic MK $5 \mathrm{~J}$. W. Lemmens measurement equipment.

\subsubsection{Sample preparation}

The cement mortar samples $(40 \times 40 \times 160) \mathrm{mm}$ were prepared according to the EN 196-1 standard. ${ }^{17}$ The water-to-cement ratio used was 0.45 . The flow value of the fresh cement mortar was $141 \pm 9 \mathrm{~cm}$, as measured by the flow-table test described in the EN 1015-3 standard. ${ }^{18}$ The mortar bars were cured and hardened in an environment with a relative humidity above $90 \%$ and a temperature of $20 \pm 1{ }^{\circ} \mathrm{C}$ for $28 \mathrm{~d}$ (days). At the age of $28 \mathrm{~d}$ they were exposed to accelerated test conditions, simulated by a 1-M aqueous solution of $\mathrm{NaOH}$ at $60{ }^{\circ} \mathrm{C}$ or deionized water at $60{ }^{\circ} \mathrm{C}$. The samples were submitted to analyses after $1 \mathrm{~m}$ (month), $3 \mathrm{~m}, 6 \mathrm{~m}$ and $1 \mathrm{y}$ (year) of aging, with the exception of the elasticity modulus, where measurements were carried out more frequently. The denotation of the samples consists of number 1 or 2 , for the deionized water or the $1-\mathrm{M} \mathrm{NaOH}$ solution, respectively. It can be extended by the exposure time to the accelerated conditions, which is $0 \mathrm{~m}$, and $1 \mathrm{~m}, 3 \mathrm{~m}, 6$ $\mathrm{m}$ and $1 \mathrm{y}$ for the start of the ageing, and $1 \mathrm{~m}, 3 \mathrm{~m}, 6 \mathrm{~m}$ and 1 y of ageing, respectively.

\section{RESULTS AND DISCUSSION}

\subsection{Optical and electron microscopy}

The optical microscopy was conducted on samples aged for $1 \mathrm{~m}, 3 \mathrm{~m}, 6 \mathrm{~m}$ or $1 \mathrm{y}$. The progress of ACR is demonstrated in Figure 1, for samples exposed to the $1-\mathrm{M}$ aqueous solution of $\mathrm{NaOH}$ at $60{ }^{\circ} \mathrm{C}$. Two apparent features can be unambiguously observed in the aged mortar: 1) areas of changed colour of the cement paste in the vicinity of aggregate/paste boundary and 2) areas of dedolomitised reaction rims in aggregates. The dedolomitised reaction rims are observed in optical images as an alteration of the original grey colour of the sparite crystals to the brownish appearance of the secondary products. In contrast, changes in the cement binder are observed in images as dark zones close to dedolomitised sparite crystals.

Under the SEM, dedolomitisation is visible as the characteristic myrmekitic texture ${ }^{7}$ (Figure 2). The dedolomitised areas are characterised by separated and alternating phases of calcium carbonate (pale-grey areas in Figure 2b) and magnesium hydroxide (dark-grey areas in Figure 2b). Because the dedolomitisation reaction requires a humid environment and also involves mobile ionic species, it is best represented when written as an ionic Equation (1). 
P. ŠTUKOVNIK et al.: MICROSTRUCTURAL CHANGES IN CEMENT MORTAR DUE TO ...

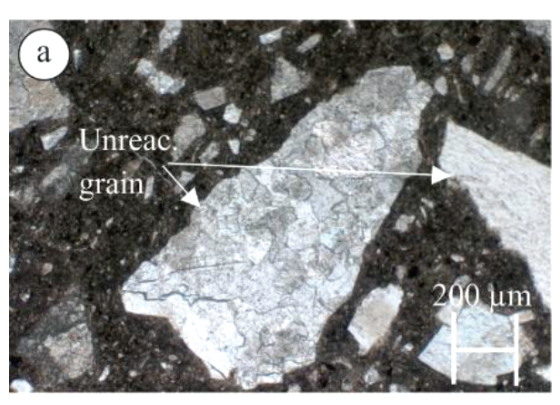

2 - 0

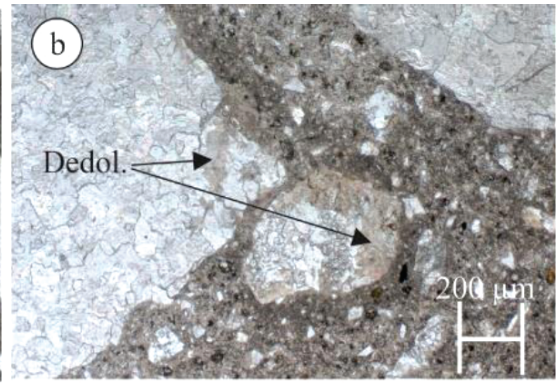

$2 \_1 \mathrm{~m}$

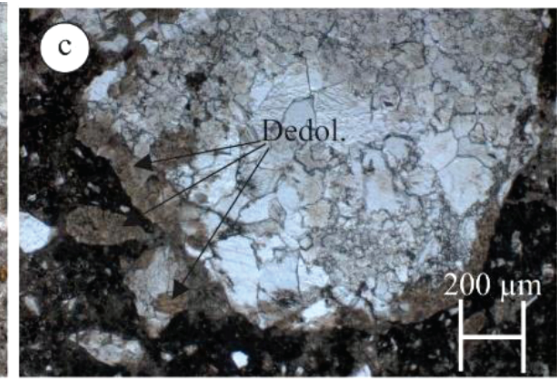

$2 \_3 m$

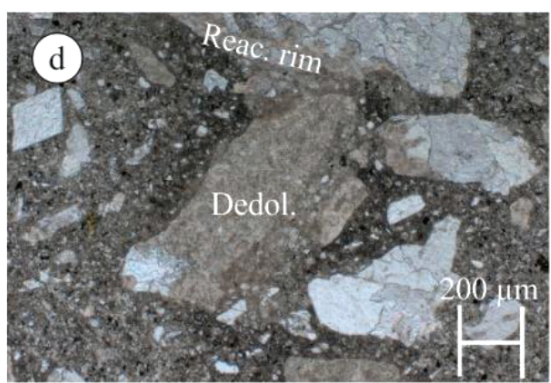

2_6m

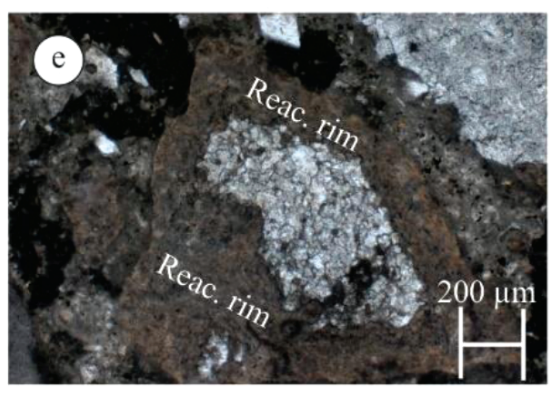

$2+1 \mathrm{y}$

Figure 1: Progress of dedolomitisation process with time
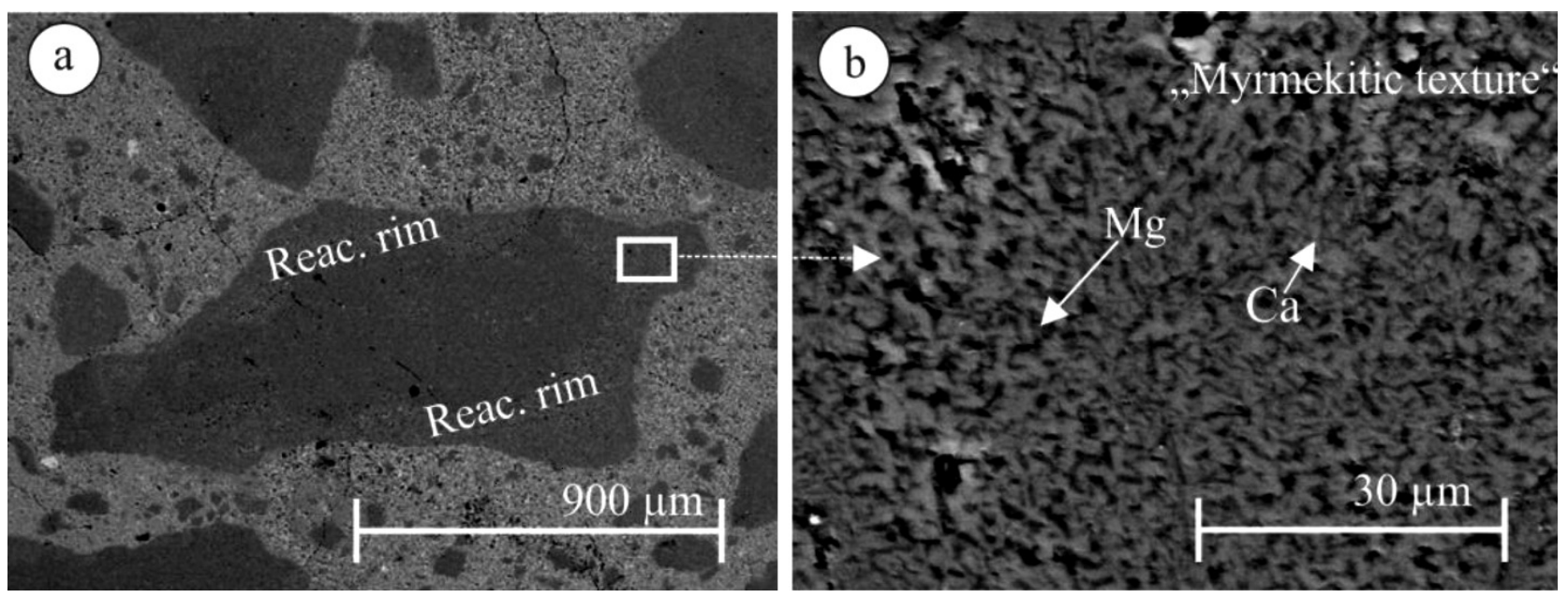

Figure 2: Process of dedolomitisation in sample 2 (after $6 \mathrm{~m}$ )
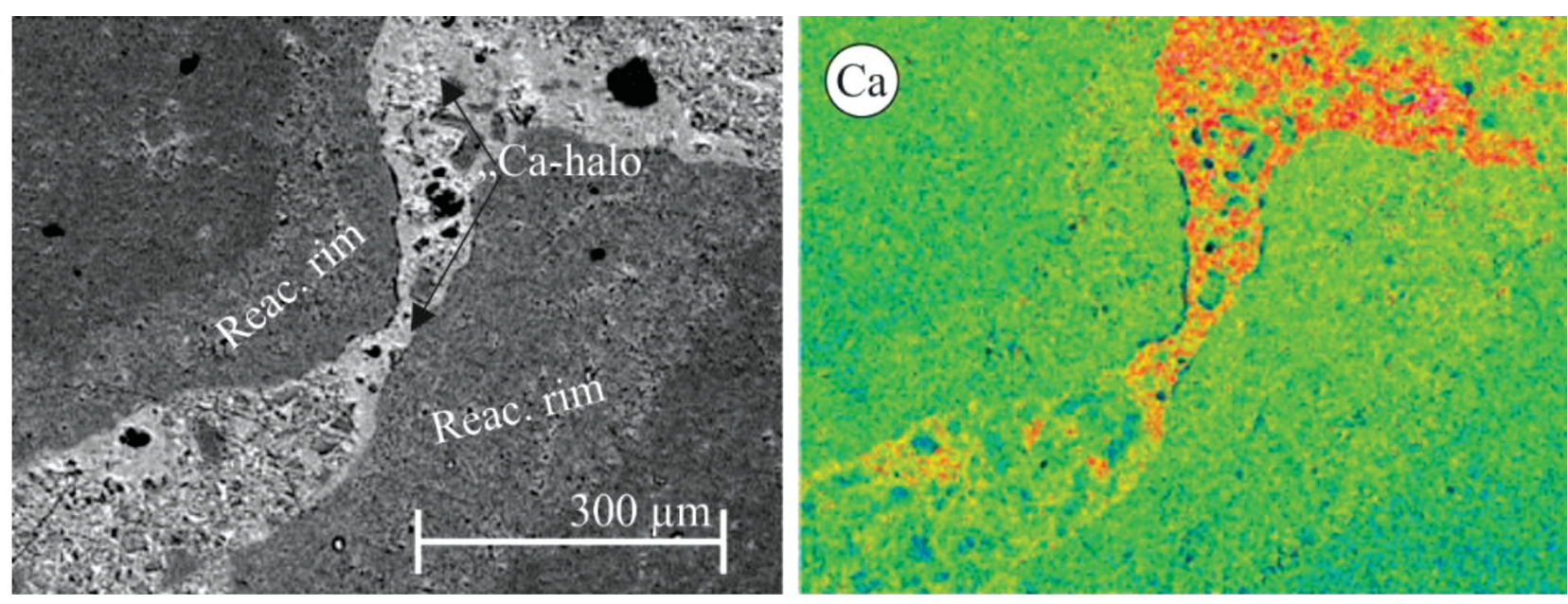

Figure 3: Formation of "Ca halo" in sample 2 (after $6 \mathrm{~m}$ ) 
$\mathrm{CaMg}\left(\mathrm{CO}_{3}\right)_{2}+2 \mathrm{OH}_{\text {aq }}^{-} \rightarrow \mathrm{Mg}(\mathrm{OH})_{2}+\mathrm{CaCO}_{3}+\mathrm{CO}_{3 \text { aq }}^{2-}$ dolomite brucite calcite

The progressing dedolomitisation reaction also causes the formation of secondary calcium carbonate often named carbonate halo or "Ca-halo". The formation of the Ca-halo (Figure 3) follows Equation (2) and can be observed close to the aggregate/cement phase boundary. During the dedolomitisation, some of the liberated $\mathrm{CO}_{3}{ }^{2-}$ ions are not consumed by the calcite formation inside the dedolomitised reaction rim and migrate towards the edge of the decaying aggregate grain as well as into the pores of the cement paste, where they meet portlandite and precipitate as Ca-halo.

$$
\begin{aligned}
& \mathrm{Mg}(\mathrm{OH})_{2}+\mathrm{CO}_{3 \text { aq }}^{2-} \rightarrow \mathrm{CaCO}_{3}+2 \mathrm{OH}_{\mathrm{aq}}^{-} \\
& \text {portlandite carbonate halo }
\end{aligned}
$$

The process of dedolomitisation is progressive with time. In the $1-\mathrm{M}$ aqueous solution of $\mathrm{NaOH}$ at $60{ }^{\circ} \mathrm{C}$, dolomite grains undergo first unambiguous dedolomitisation already after one $\mathrm{m}$ and the reaction rims are clearly visible after three $\mathrm{m}$ (Figure 1c). The dolomite grains of $\approx 1 \mathrm{~mm}$ in diameter and smaller are completely dedolomitised after $1 \mathrm{y}$, while larger dolomite grains can still have unaffected dolomite cores (Figure 1e).
If the $\mathrm{NaOH}_{\mathrm{aq}}$ is replaced by the deionised water, the dedolomitised reaction rim grows $\approx 25 \mu \mathrm{m}$ in thickness in $1 \mathrm{y}$. This suggests that, in comparison to the $\mathrm{NaOH}$ environment, dedolomitisation proceeds approximately 40 times slower in an aqueous environment. Of course, this estimation is rather rough and depends on the $\mathrm{pH}$ value of the system. However, phase transformations and microstructure changes seem to be the same in both cases, indicating that the alkaline nature of the cement paste itself is also sufficient to start the ACR reaction in an aqueous environment.

Additionally to the dedolomitisation and $\mathrm{Ca}$-halo formation the ACR process also results in the appearance of Al- and Si-involving phases. These new phases are first observed in the $\mathrm{NaOH}$ aged samples after $3 \mathrm{~m}$ and $6 \mathrm{~m}$, respectively. In contrast, an ageing period of $1 \mathrm{y}$ in the $\mathrm{H}_{2} \mathrm{O}$ environment is still not sufficiently long to trigger their precipitation. The formation of Al- or/and Si-involving phases can be chemically described with the Equations (3-5).

$$
\begin{aligned}
& 6\left[\mathrm{CaMg}\left(\mathrm{CO}_{3}\right)_{2}\right]+2 \mathrm{Al}(\mathrm{OH})_{4 \text { aq }}^{-}+8 \mathrm{OH}_{\text {aq }}^{-}+4 \mathrm{H}_{2} \mathrm{O} \rightarrow \\
& \text { dolomite } \\
& \rightarrow 6 \mathrm{MgO} \cdot \mathrm{Al}_{2} \mathrm{O}_{3} \cdot \mathrm{CO} 2 \cdot 12 \mathrm{H}_{2} \mathrm{O}+6 \mathrm{CaCO}_{3}+5 \mathrm{CO}_{3 \mathrm{aq}}^{2-} \\
& \text { hydrotalcite calcite }
\end{aligned}
$$
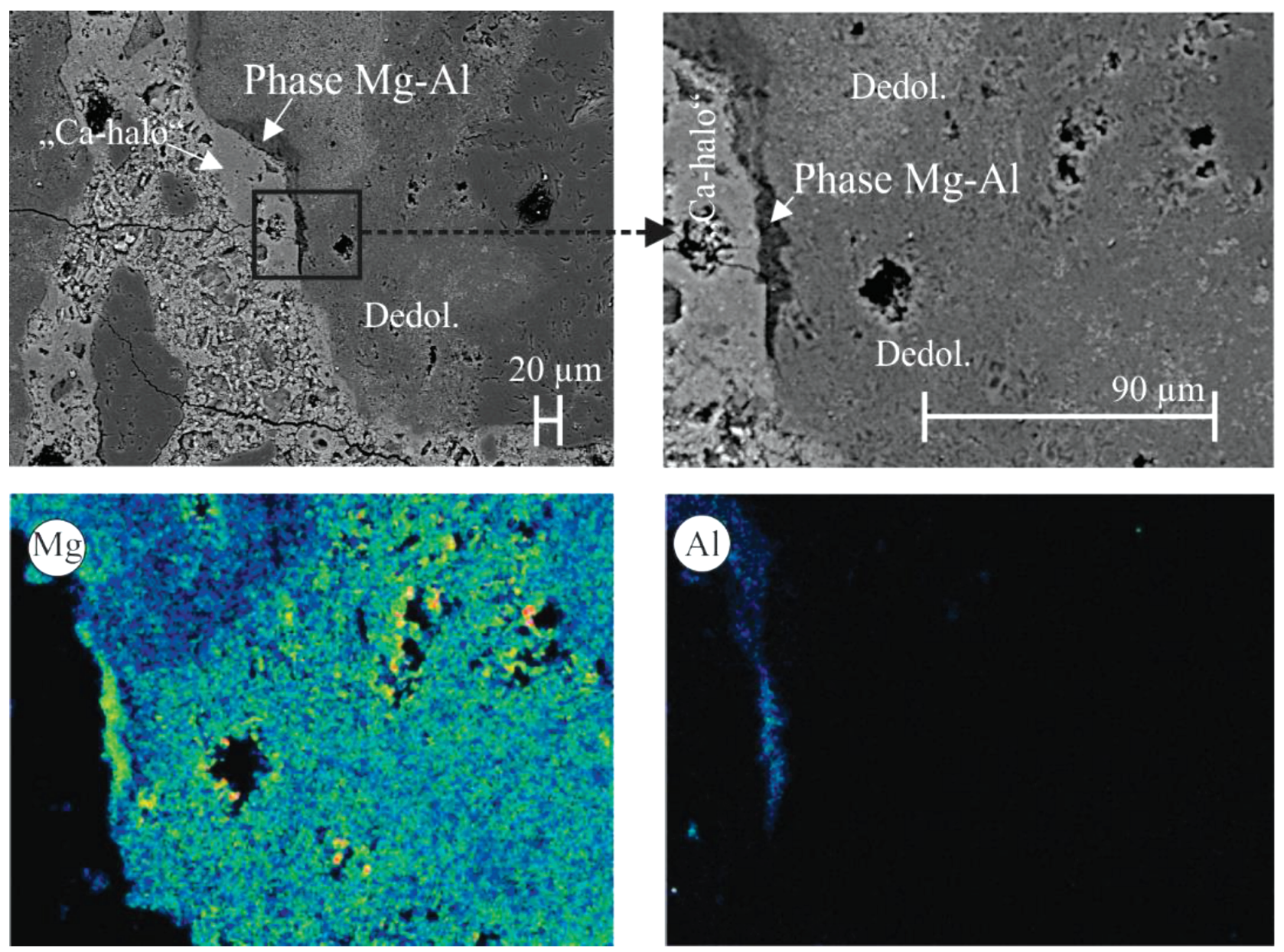

Figure 4: Formation of $\mathrm{Mg}-\mathrm{Al}$ phase in sample 2 (after $3 \mathrm{~m}$ ) 
P. ŠTUKOVNIK et al.: MICROSTRUCTURAL CHANGES IN CEMENT MORTAR DUE TO ..
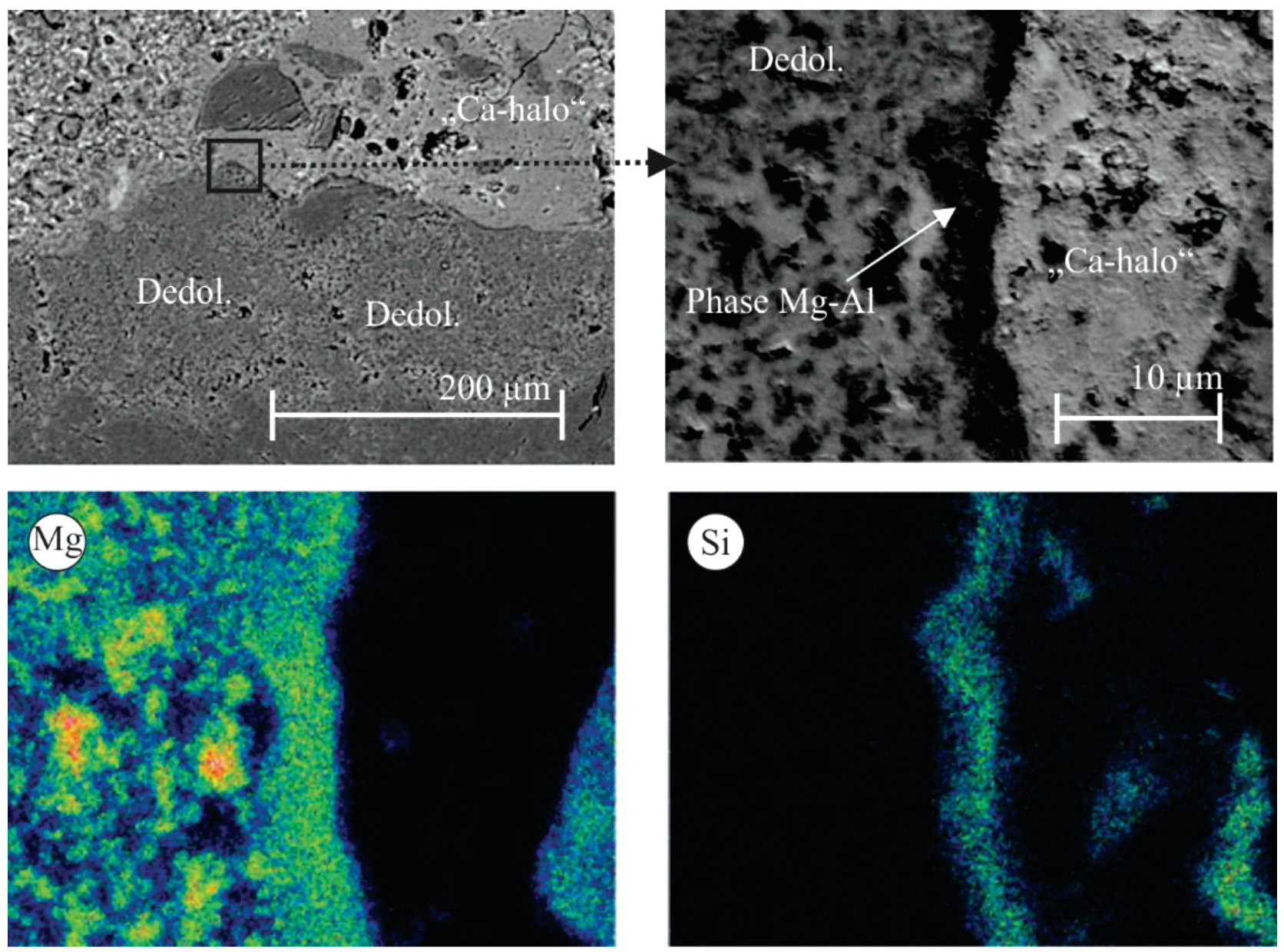

Figure 5: Formation of Mg-Si phase in sample 2 (after $6 \mathrm{~m}$ )
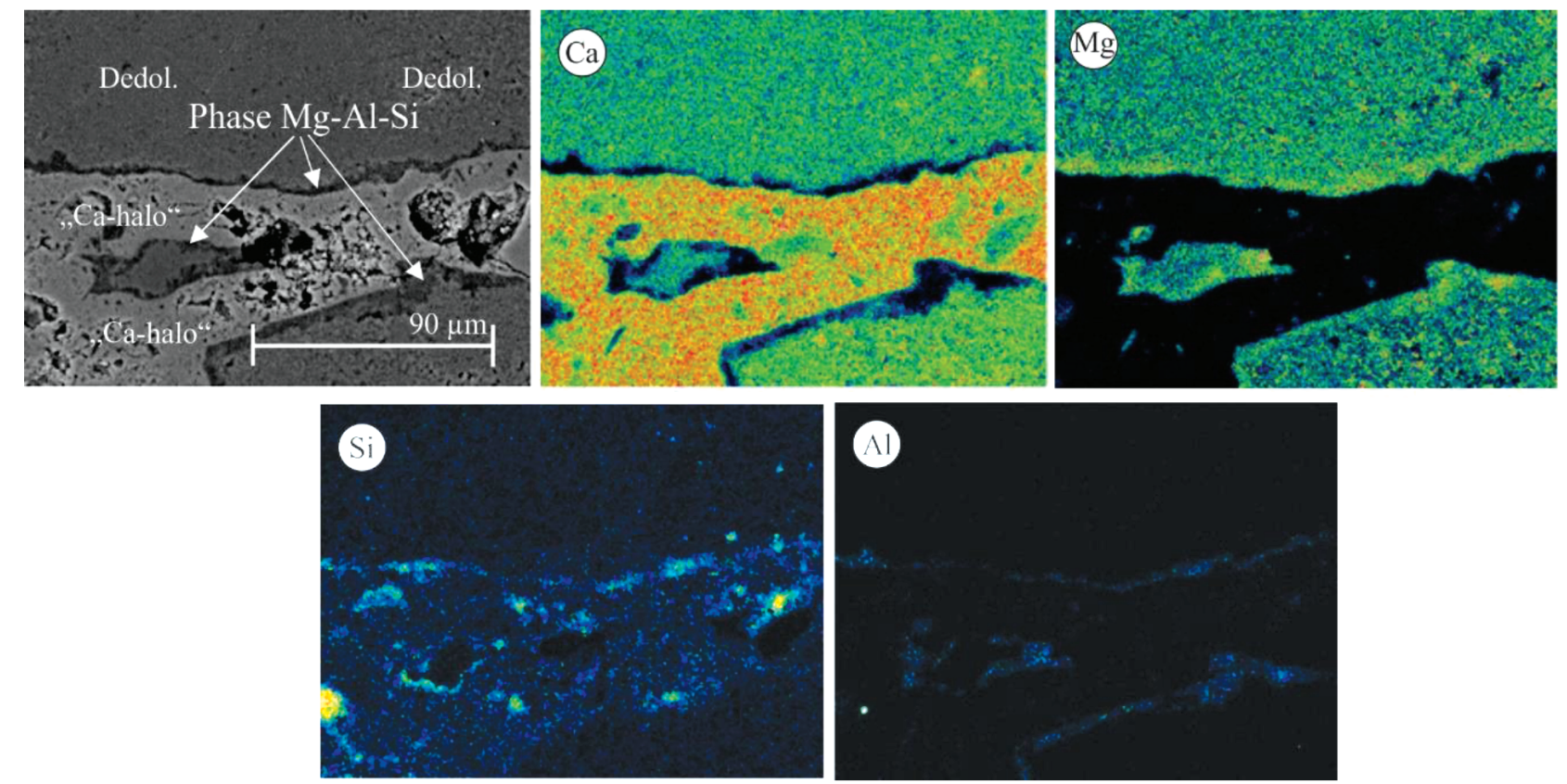

Figure 6: Formation of $\mathrm{Mg}-\mathrm{Si}-\mathrm{Al}$ phase in sample 2 (after 1 y) 


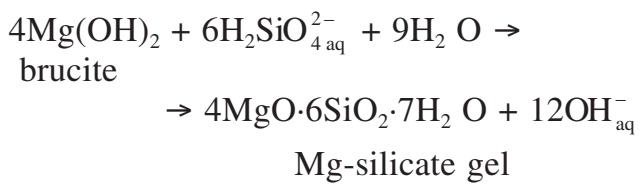

(4)

$$
\begin{aligned}
& 4 \mathrm{MgO} \cdot 6 \mathrm{SiO}_{2} \cdot 7 \mathrm{H}_{2} \mathrm{O}+6 \mathrm{Mg}(\mathrm{OH})_{2}+4 \mathrm{Al}(\mathrm{OH})_{4 \text { aq }}^{-} \rightarrow \\
& \mathrm{Mg} \text {-silicate gel brucite } \\
& \rightarrow 2\left[5 \mathrm{MgO} \cdot \mathrm{Al}_{2} \mathrm{O}_{3} \cdot 3 \mathrm{SiO}_{2} \cdot 4 \mathrm{H}_{2} \mathrm{O}\right]+4 \mathrm{OH}_{\mathrm{aq}}^{-}+11 \mathrm{H}_{2} \mathrm{O} \\
& \text { clinochlore }
\end{aligned}
$$

Chronologically, the Mg-Al-phase (hydrotalcite) is observed first after $3 \mathrm{~m}$ of ageing in a $\mathrm{NaOH}$ environment (Figure 4). Hydrotalcite precipitation is possible due to the fact that aluminate ions $\mathrm{Al}(\mathrm{OH})_{4}^{-}$originate from the soluble nature of alumina, involving minerals in the cement paste (i.e., tricalcium aluminate $3 \mathrm{CaO} \cdot \mathrm{Al}_{2} \mathrm{O}_{3}$ and tetracalcium aluminaferrite $4 \mathrm{CaO} \cdot \mathrm{Al}_{2} \mathrm{O}_{3} \cdot \mathrm{Fe}_{2} \mathrm{O}_{3}$ ) under alkaline conditions. ${ }^{8}$

After $6 \mathrm{~m}$ of ageing a new Mg-Si-phase can be found (Mg-silicate gel). The necessary silicate ions, which took part in the precipitation of the secondary $\mathrm{Mg}$-Si phase at the aggregate-cement paste interface, are supplied from the CSH decomposition/regeneration cycle. ${ }^{8}$ The $\mathrm{Mg}$-silicate forms mostly as a reaction rim around the decaying aggregate grain and can be disconnected at several spots (Figure 5). It is reasonable to assume that in this reaction system $\mathrm{H}_{2} \mathrm{SiO}_{4}{ }^{2-}$ ions are mobile species diffusing through the porous hydrated cement paste toward the surface of the decaying aggregate grains. With time the Mg-Al- and $\mathrm{Mg}$-Si phases transform into a new $\mathrm{Mg}$-Si-Al-phase by consecutively reacting with $\mathrm{H}_{2} \mathrm{SiO}_{4}{ }^{2-}$ or $\mathrm{Al}(\mathrm{OH})_{4}{ }^{-}$ions, respectively (Figure 6).

\subsection{X-ray diffraction analysis}

The ageing process in cement mortar is also investigated using X-ray powder diffraction. It is evident that only the expected crystalline phases, i.e., dolomite (PDF no. 000-36-0426), calcite (PDF no. 000-05-0586), brucite (PDF no. 000-74-2220) and portlandite (PDF no.

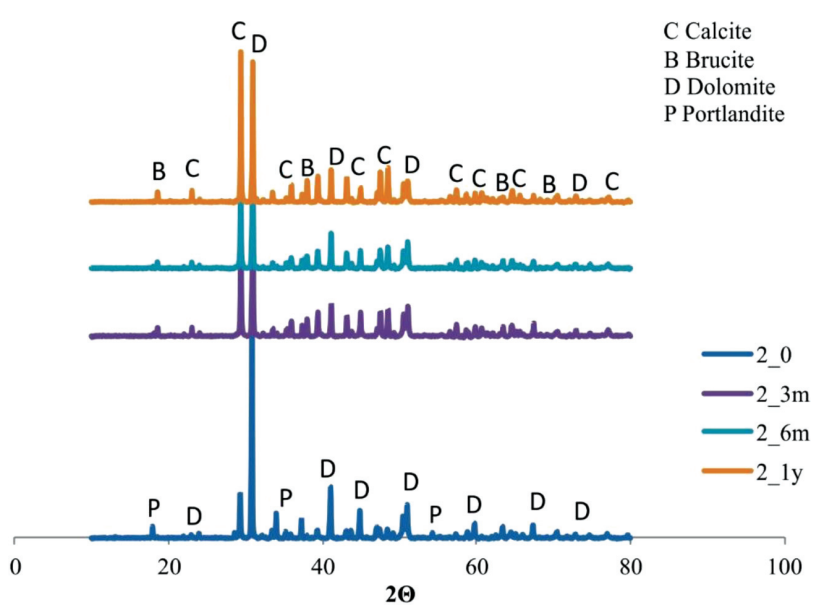

Figure 7: Crystalline phase development in sample 2
000-04-0733) are found in the investigated systems. Since secondary phases in aged cement mortars, which appear with time, are present in rather limited amounts, they are very difficult to follow with X-ray powder diffraction. As expected, dolomite and portlandite progressively vanish, while brucite and calcite gradually form (Figure 7). However, these gradual phase amount changes are far more distinctive in the $\mathrm{NaOH}$ - in comparison to the $\mathrm{H}_{2} \mathrm{O}$-aged mortar bar. During ageing in $\mathrm{NaOH}$, the amount of calcite practically exceeds the amount of dolomite after $12 \mathrm{~m}(46.4 \%$ calcite and $42.7 \%$ dolomite). After the same ageing period the amount of brucite is close to $9.5 \%$, while the amount of portlandite basically becomes negligible. In the $\mathrm{H}_{2} \mathrm{O}$ environment amounts of calcite, dolomite, brucite and portlandite after $12 \mathrm{~m}$ of ageing are calculated as $19.45 \%, 75.3 \%, 1.3 \%$ and $3.9 \%$, respectively.

\subsection{Mechanical properties}

Flexural and compressive tests of the mortar bars after various accelerated ageing periods were conducted on 3 and 6 parallel specimens, respectively. The reference mean values of the compressive and flexural strengths of the mortar were taken prior to the ageing (ageing time of $0 \mathrm{~d}$ ) as $84 \mathrm{MPa}$ (for compressive strength) and $11 \mathrm{MPa}$ (for flexural strength). When compared to the same properties of the cement mortar studied in ${ }^{19}, 63 \mathrm{MPa}$ and $9.5 \mathrm{MPa}$ for compressive and
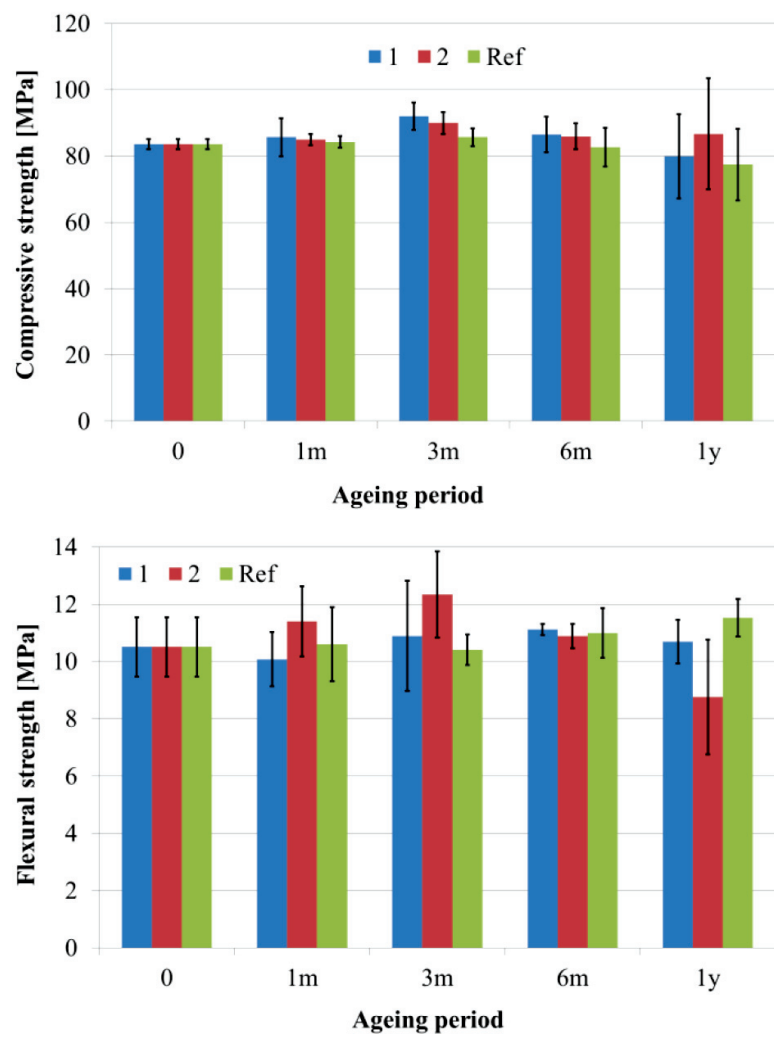

Figure 8: Strength of the mortar bars: a) compressive strength, b) flexural strength 


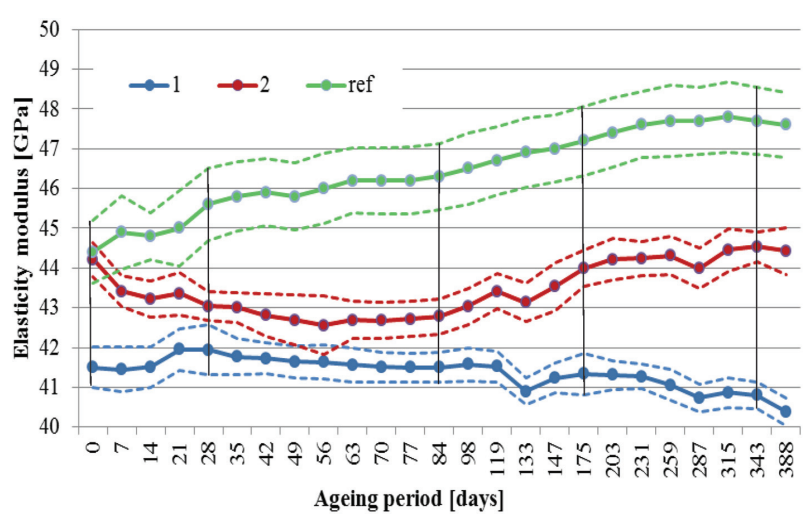

Figure 9: Changes in elasticity modulus of samples 1 and 2, compared to samples in water at $20{ }^{\circ} \mathrm{C}$

flexural strength, respectively, these strengths are considerably higher. One part of the increased strength is a consequence of the cement type used (CEM I 52.5 R ver. CEM I $42.5 \mathrm{R} \mathrm{in}^{19}$ ). The second part is due to the parent rock used as the source of the dolomite aggregate for the cement mortar. The parent rock used in ${ }^{19}$ is described in ${ }^{2}$ and we can see that even crushed aggregate grains contain a lot of tectonic cracks of different sizes, which are filled with sparite cement. We can conclude that this is main reason for the considerably lower reference strengths of the cement mortar in a previous study. ${ }^{19}$ Moreover, in $^{2}$ the process of dedolomitisation started usually along these pre-existing cracks, as the contact between the micrite base and the sparite cement inside the crack is a weak point through which alkali ions from the alkaline solution can easily enter, allowing the process of recrystallisation to start. Similar tectonic cracks and the associated dedolomitisation process were not observed in the cement mortar prepared with dolomite aggregate from the south-eastern part of Slovenia.

The mean values of the compressive and flexural strengths of samples 1 and 2, with standard deviations, are presented in Figure 8. It is important to emphasise that the strengths were measured on different sets of mortar bars for each ageing period, due to the destructive nature of the tests. In Figure 9 the results of continuous measurements of the modulus of elasticity (E-modulus) are presented, as mean values and associated standard deviations. In this case the test was carried out on the same set of samples for all the ageing times, due to the non-destructive nature of the applied test method. A larger variation of the test results is typical for the destructive test methods, when studying the time-dependent properties of cement mortar.

As reference results (Ref) that allow us to evaluate the influence of the ACR processes on the cement mortar mechanical properties, we also give data for the cement mortar aged in water at $20 \pm 1{ }^{\circ} \mathrm{C}$, which is a standard approach for non-accelerated ageing in concrete technology. For the ref samples we can observe constant compressive and flexural strengths up to $3 \mathrm{~m}$. After that a slow increase of the flexural strength (for $10 \%$ ), and the same time slow decrease of compressive strength (for $7 \%$ ) occurred. The E-modulus increases slowly but steadily, for the ageing period between $0 \mathrm{~d}$ and $315 \mathrm{~d}$, when it reaches an $8 \%$ higher value. According to common knowledge in the concrete technology, the increase in the E-modulus of the Ref samples is related to the ongoing hydration of the cement binder. The same mechanism can also be responsible for the detected increase in the flexural strength. However, also a gain in the compressive strength with time is expected due to the cement hydration, which is not the case in our study. The observed discrepancy will not be addressed in this paper. We will use the Ref data only as a comparison to discuss the results of the mechanical tests of specimens 1 and 2 .

The mean compressive strengths of samples 1 and 2 do not differ significantly from those of the Ref samples, although a slight increase in the compressive strength, due to ACR, can be observed, especially for the samples 2 at an ageing period of 1 y (Figure 8a). Flexural strength (Figure 8b) and E-modulus (Figure 9) seem to better reflect the progress of the ACR processes on the micro level. First, we will focus on the response of specimens 2, where the ACR progress is fast. In Figure 9 we can observe a decrease of the E-modulus up to $2 \mathrm{~m}$, after which approximately constant values were measured up to $3 \mathrm{~m}$. The reduction in the E-modulus is accompanied by an increase of the flexural strength, for the ageing periods of 1 and $3 \mathrm{~m}$ (Figure $\mathbf{8 b}$ ). After $3 \mathrm{~m}$ the E-modulus starts to increase steadily until $1 \mathrm{y}$ of accelerated ageing, with the exception of two drops at $133 \mathrm{~d}$ and 287 d. This increase in the E-modulus is accompanied by a considerable decrease of the mean flexural strength at 6 $\mathrm{m}$ and $1 \mathrm{y}$ of ageing. In the case of samples 1 an increase of the E-modulus in the first month of accelerated ageing is related to the drop of the flexural strength at $1 \mathrm{~m}$. After that the mean flexural strength of the samples 1 increases up to $6 \mathrm{~m}$. At $1 \mathrm{y}$ reduction of the mean flexural strength, compared to the Ref samples, can be observed.

A gradual decrease in the E-modulus of the cement mortar with time, when the mortar was exposed to the $1 \mathrm{M}-\mathrm{NaOH}$ solution at $60{ }^{\circ} \mathrm{C}$, could be explained with the process of dedolomitisation evidenced by the formation of reaction rims, where the dolomite crystals were replaced by the reaction products, brucite and calcite. An increased porosity in the dolomite grains was also observed in the earlier study, ${ }^{2}$ which is in agreement with the equation of dedolomitisation given in ${ }^{8}$, with a volume change of $-5.1 \varphi / \%$. A gradual increase in the porosity of the dolomite aggregate grains, due to dedolomitisation, is a plausible cause for the observed decrease in the E-modulus, since the properties of the aggregate grains have the most prevailing influence on this characteristic.

The increase in the flexural strength, parallel to the E-modulus decrease, can be explained so far by the formation of secondary calcium carbonate along the dedolomitised aggregate grains, observed under a polarizing microscope as an alteration of the cement binder, 
and with SEM/EDS as an increased concentration of $\mathrm{Ca}$ atoms. A higher density of the cement binder along the edges of the dedolomitisated grains, due to the formation of secondary calcium carbonate, is a realistic source of the strength increase.

When the E-modulus of the specimens 2 started to increase again, new phases (Mg-Al after $3 \mathrm{~m}, \mathrm{Mg}-\mathrm{Si}$ after $6 \mathrm{~m}$ and $\mathrm{Mg}$-Si-Al after $1 \mathrm{y}$ ) were detected using the SEM/EDS. The formation of these phases could be responsible for the observed increase of the E-modulus and the simultaneous decrease in the flexural strength for the specimens 2. Moreover, the new phases could also increase the compressive strength of the cement mortar, along with the secondary calcium carbonate formed in the hydrated cement paste around the dedolomitised aggregate grains. In this way a reduction of the compressive strength due to the increased porosity of the dolomite aggregate grains can be compensated, as illustrated by the mean compressive strength of the samples 2 after $1 \mathrm{y}$ of accelerated ageing (Figure 8a).

\section{CONCLUSIONS}

This paper assesses the non-expansive alkali-carbonate reaction (ACR) in cement mortar prepared using selected silica-free dolomite aggregate in relation to their microstructural and mechanical properties. From the obtained results, the following major conclusions can be drawn:

- Dedolomitisation, triggered by hydroxyl ions, occurred as a rule within the reaction rims.

- Silicate ions, which took part in the precipitation of the secondary $\mathrm{Mg}-\mathrm{Si}$ or $\mathrm{Mg}-\mathrm{Al}-\mathrm{Si}$ phases at the aggregate-cement paste interface, were supplied from the CSH decomposition/regeneration cycle. Aluminate ions, which took part in the precipitation of the $\mathrm{Mg}-\mathrm{Al}$ or $\mathrm{Mg}-\mathrm{Al}-\mathrm{Si}$ phases, originated from the soluble nature of the alumina involving minerals in the cement paste.

- At the aggregate-cement paste boundary, the new $\mathrm{Mg}$-Al phase formed earlier than the $\mathrm{Mg}$-Si phase. Eventually, both new phases transformed into the Mg-Si-Al phase, the chemical composition of which can change locally and with time.

- Phase transformations during the ACR were the same in the $\mathrm{NaOH}$ or the aqueous environment.

- The more alkaline nature of the $\mathrm{NaOH}$ environment substantially accelerated the ACR process.

- Dedolomitisation, the formation of secondary calcium carbonate and the formation of $\mathrm{Mg}-\mathrm{Si}-\mathrm{Al}-$ involving secondary phases in the investigated cement mortar reflected in an alteration of its mechanical properties. The dynamic modulus of elasticity and the flexural strength seem to be the two properties that reflect these changes more clearly than the compressive strength.

\section{REFERENCES}

${ }^{1}$ M. R. Smith, Stone: Building Stone, Rock Fill and Armourstone in Construction, The Geological Society, London 1999, 478

${ }^{2}$ P. Štukovnik, T. Prinčič, R. S. Pejovnik, V. Bokan Bosiljkov, Alkalicarbonate reaction in concrete and its implications for a high rate of long-term compressive strength increase, Constr. Build. Mater., 50 (2014), 699-709, doi:10.1016/j.conbuildmat.2013.10.007

${ }^{3}$ P. Štukovnik, M. Marinšek, B. Mirtič, V. Bokan Bosiljkov, Influence of alkali carbonate reaction on compressive strength of mortars with air lime binder, Constr. Build. Mater., 75 (2015), 247-254, doi:10.1016/j.conbuildmat.2014.11.024

${ }^{4}$ T. Prinčič, P. Štukovnik, S. Pejovnik, G. de Schutter, V. Bokan Bosiljkov, Observations on dedolomitization of carbonate concrete aggregates, implications for ACR and expansion, Cem. Concr. Res., 54 (2013), 151-160, doi:10.1016/j.cemconres.2013.09.005

${ }^{5}$ H. H. Newlon Sherwood, W. C., An occurrence of alkali-reactive carbonate rock in Virginia, Highw. Res Board Bull., (1962), 27-44

${ }^{6}$ M. Deng, S. F. Han, Y. N. Lu, X. H. Lan, Y. L. Lu, M. S. Tang, Deterioration of concrete structures due to alkali-dolomite reaction in China, Cem. Concr. Res., 5 (1993), 1040-1046

${ }^{7}$ T. Katayama, How to identify carbonate rock reactions in concrete, Mater. Charact., 53 (2004) 85-104, doi:10.1016/j.matchar.2004. 07.002

${ }^{8}$ T. Katayama, The so-called alkali-carbonate reaction $(A C R)-$ its mineralogical and geochemical details, with special reference to ASR, Cem. Concr. Res., 40 (2010) 643-675, doi:10.1016/ j.cemconres.2009.09.020

${ }^{9}$ B. D. Evamy, Dedolomitization and the development of rhombohedral pores in limestones, J. Sediment. Petrol., 37 (1967), 1204-1215

${ }^{10}$ P. Štukovnik, M. Marinsek, V. Bokan-Bosiljkov, Observation of reactions between dolomite aggregate grains and lime-based binder in lime mortars, Abstr. $3^{\text {rd }}$ Hist. Mortars Conf. HMC 13, Glasgow, 2013, 108

${ }^{11}$ D. Dębska, The effect of exposition conditions on the durability of cement concrete with dolomite aggregate sourced near Kraków, Poland, Procedia Eng., 108 (2015), 673-680, doi:10.1016/j.proeng. 2015.06.198

${ }^{12}$ D. Min, T. Mingshu, Mechanism of dedolomitization and expansion of dolomitic rocks, Cem. Concr. Res., 23 (1993), 1397-1408, doi:10.1016/0008-8846(93)90077-M.

${ }^{13}$ M. Plenicar, U. Premrl, M. Herak, J. Cajhen, L. Ferjancic, K. Grad, P. Mioc, D. Novak, L. Prah, L. Sribar, D. Turnsek, J. Volk, D. Vujic, Geological map of SFRJ, L33-79, Novo mesto [map], 1:100.000, (in Slovenian), Federal Geological Institute, Belgrade 1975

${ }^{14}$ M. Plenicar, U. Premrl, M. Herak, J. Cajhen, L. Ferjancic, K. Grad, P. Mioc, D. Novak, L. Prah, L. Sribar, D. Turnsek, J. Volk, D. Vujic, U. Premru, Geological map of SFRJ, 1:100.000, Interpreter map of Novo mesto, L33-79 (in Slovenian), Federal Geological Institute, Belgrade 1977

${ }^{15}$ D. A. St. John, A. B. Poole, I. Sims, Concrete Petrography, $1^{\text {st }}$ ed., Arnold, a Member of the Hodder Headline Group, New York 1998, 488

${ }^{16}$ J. Ingham, Geomaterials under the microscope, Mason Publishing, London 2011, 192

${ }^{17}$ SIST EN 196-1:2005 Methods of testing cement - Part 1: Determination of strength, Slovenian Institute for Standardisation, Ljubljana

${ }^{18}$ SIST EN 1015-3:2001 Methods of test for mortar for masonry - Part 3: Determination of consistence of fresh mortar (by flow table), Slovenian Institute for Standardisation, Ljubljana

${ }^{19}$ P. Štukovnik, M. Marinsek, V. Bokan-Bosiljkov, Influence of mineral binder type on alkali carbonate reaction, RILEM Proc. PRO 107, Paris 2017, 8 